\title{
Zasady finansowania systemu ochrony zdrowia w Wielkiej Brytanii ${ }^{1}$
}

\section{Principles of the health system funding in Great Britain}

Streszczenie. W opracowaniu zbadano główne źródła finansowania ochrony zdrowia o charakterze publicznoprawnym w Wielkiej Brytanii. Artykuł przedstawia także podstawowe zasady organizacji systemu zdrowotnego w tym kraju. Wskazano w nim na wady i zalety budżetowego modelu ochrony zdrowia. Ustalono również, iż budżet państwa nie jest jedynym źródłem finansowania Narodowej Służby Zdrowia. Część środków przeznaczanych na realizację jej zadań pochodzi bowiem ze składek na ubezpieczenie społeczne.

Słowa kluczowe: finansowanie ochrony zdrowia.

Abstract. The study examined the primary sources of public health funding in Great Britain. Moreover, the article presents the basic organisational principles of the health system in the country. It points out the advantages and disadvantages of

1 Opracowanie przygotowane w ramach projektu pt. „Źródła finansowania ochrony zdrowia w Polsce - aspekty prawne” finansowanego w konkursie PRELUDIUM 8 organizowanym przez Narodowe Centrum Nauki (nr projektu: 2014/15/N/HS5/01735). 
the budget model of health care. It also established that the state budget is not the only source of funding for the National Health Service. A portion of the funds allotted to the implementation of its tasks come from social security contributions.

Keywords: health system funding.

\section{Wprowadzenie}

Powszechnie funkcjonującym w państwach Unii Europejskiej modelem organizacji i finansowania ochrony zdrowia jest model budżetowy ${ }^{2}$. Został on wprowadzony po raz pierwszy w Wielkiej Brytanii w 1946 r. Był to zarządzany centralnie, powszechnie dostępny i bezpłatny system ochrony zdrowia. Podstawą dla stworzenia brytyjskiego modelu ochrony zdrowia był raport Williama Beveridge’a ${ }^{3}$ „Ubezpieczenia społeczne i służby pokrewne” (Social Insurance and Allied Services) sporządzony 1 grudnia $1942 \mathrm{r}^{4}$

Raport Beveridge’a przewidywał, poza stworzeniem powszechnej służby zdrowia, wprowadzenie systemu zasiłków rodzinnych oraz polityki pełnego zatrudnienia. Wskazywano w nim na konieczność funkcjonowania nieodpłatnej i powszechnie dostępnej opieki zdrowotnej. Ochrona zdrowia opierała się na trzech zasadach: powszechności, jednolitości oraz równości. Zgodnie z zasadą powszechności ochrona zdrowia obejmowała wszystkich obywateli bez względu na pozycję społeczną lub wykonywany zawód. Według zasady jednolitości ochroną zdrowia zarządzał jeden spójny system administracyjny. Równość oznaczała natomiast gwarancję otrzymania przez obywatela określonych świadczeń zdrowotnych w niezbędnej dla jego potrzeb ilości ${ }^{5}$.

\footnotetext{
Nazywany także modelem Narodowej Służby Zdrowia (National Health Service).

Dlatego też model ochrony zdrowia funkcjonujący w Wielkiej Brytanii nazywany jest modelem Beveridge'a.

4 M. Urbaniak, Aspekty publicznoprawne organizacji i finansowania ochrony zdrowia w Republice Włoskiej, Toruń 2014, s. 39.

5 A. Depta, Transformacja współczesnych systemów zdrowotnych $w$ wybranych krajach, [w:] J. Suchecka (red.), Finansowanie ochrony zdrowia. Wybrane zagadnienia, Warszawa 2011, s. 33-34.
} 
Narodowa Służba Zdrowia charakteryzuje się przede wszystkim nałożeniem na państwo odpowiedzialności za organizację ochrony zdrowia i zapewnienie świadczeń opieki zdrowotnej. Cele systemu ochrony zdrowia są realizowane przez organy administracji państwowej. Państwo nie przerzuca obowiązków w zakresie organizacji systemu na inne podmioty (np. kasy chorych funkcjonujące w modelu Bismarcka). Decyzje w zakresie organizacji i finansowania systemu są scentralizowane i zależą przede wszystkim od uwarunkowań politycznych ${ }^{6}$.

Model Narodowej Służby Zdrowia funkcjonuje obecnie w zmodyfikowanej wersji m.in. w Wielkiej Brytanii, Irlandii, Danii, Finlandii, Szwecji oraz we Włoszech. W związku z tym, że powszechnie występuje one w wielu państwach Unii Europejskiej, uzasadnione jest zbadanie i przedstawienie podstawowych zasad jego organizacji i finansowania obowiązujących obecnie.

Celem opracowania jest zatem przedstawienie i zbadanie zasad finansowania brytyjskiego systemu zdrowotnego jako przykładu budżetowego modelu ochrony zdrowia, którego charakter oraz konstrukcja są zasadniczo odmienne od rozwiązań prawnofinansowych funkcjonujących obecnie w Polsce.

\section{Organizacja brytyjskiego systemu ochrony zdrowia}

Pierwotna wersja modelu Beveridge’a została wprowadzona w Wielkiej Brytanii w 1948 r. Przed wejściem w życie nowych zasad funkcjonowania systemu zabezpieczenia zdrowotnego w Wielkiej Brytanii obowiązywało państwowe ubezpieczenie zdrowotne. Głównym źródłem jego finansowania były składki uiszczane przez pracowników i pracodawców, a także w części pokrywane przez państwo. Od wejścia w życie modelu budżetowego organy administracji państwowej gwarantują obywatelom świadczenia z zakresu podstawowej opieki zdrowotnej, dostęp do szpitali oraz

6 W. Włodarczyk, Polityka zdrowotna w społeczeństwie demokratycznym, ŁódźKraków-Warszawa 1996, s. 317. 
profilaktyki zdrowotnej ${ }^{7}$. Świadczenia zdrowotne osobom uprawnionym do ich pobierania zapewnia Narodowa Służba Zdrowia (National Health Service) $)^{8}$.

Narodowa Służba Zdrowia w Anglii, Irlandii Północnej, Szkocji oraz Walii jest zarządzana w sposób odrębny i niezależny. W ostatnich latach wystąpiły nieistotne różnice pomiędzy tymi systemami. Wskazuje się jednak, iż NHS stanowi jednolity system ${ }^{9}$. Podstawy prawne organizacji i finansowania systemu zdrowotnego wynikają przede wszystkich z $\mathrm{Na}$ tional Health Service Act z 2006 r. $^{10}$ oraz Health and Social Care Act z 2012 r. ${ }^{11}$, który w znacznej części stanowi nowelizację NHS Act 2006.

Za organizację brytyjskiego modelu ochrony zdrowia odpowiada głownie Departament Zdrowia, kierowany przez Sekretarza Stanu do spraw Zdrowia (Secretary of State for Health), do którego obowiązków należy utrzymanie, funkcjonowanie oraz rozwijanie NHS. Wyznacza on także cele systemu zdrowotnego, a także ma prawo do podejmowania środków nadzorczych. Secretary of State for Health jest zobowiązany do zapewnienia środków finansowych przeznaczanych na organizację i funkcjonowanie Narodowej Służby Zdrowia. Jest on odpowiedzialny za negocjowanie z Ministrem Finansów poziomu finansowania Narodowej Służby Zdrowia. Wspiera również politykę rządu w zakresie poprawy stanu zdrowia ludności ${ }^{12}$.

Do organów zarządzających brytyjskim systemem ochrony zdrowia zalicza się także: NHS Commissioning Board, The National Institute for Health and Clinical Excellence (jego obowiązkiem jest opracowywanie standardów funkcjonowania NHS), a także The Care Quality Commission (opracowuje regulacje dotyczące standardów jakości oraz bezpieczeństwa udzielanych świadczeń zdrowotnych oraz kontroluje podmioty bezpo-

\footnotetext{
S. Boyle, Health Systems in Transition. United Kingdom (England), Health System Review 2011, s. 22 i 26.

Dalej powoływana jako „NHS”.

J. Merrils, J. Fisher, Pharmacy Law and Practice, Oxford 2013, s. 11.

National Health Service Act 2006, chapter 41; dalej: „NHS Act 2006”.

Health and Social Care Act 2012, chapter 7; dalej: „HSC Act 2012”.

S. Boyle, Health Systems in Transition. United Kingdom..., s. 30.
} 
średnio udzielające tych świadczeń) ${ }^{13}$. NHS Commissioning Board jest autonomicznym organem niezależnym od administracji rządowej. Zgodnie ze schedule A1 NHS Act 2006 do jego zadań należy zlecanie świadczeniodawcom wykonywania niektórych usług zdrowotnych (m.in. świadczeń z zakresu podstawowej opieki zdrowotnej). Istotne znaczenie w strukturze organizacyjnej Narodowej Służby Zdrowia mają także Clinical Commission Groups będące korporacyjnymi podmiotami prawa publicznego. Zrzeszają one wszystkich świadczeniodawców w Anglii. Bez członkostwa w tego rodzaju korporacji nie istnieje prawna możliwość świadczenia usług zdrowotnych w ramach umowy zawartej z NHS. Do zadań Clinical Commission Groups należy przede wszystkim zapewnienie świadczeń zdrowotnych na całym terytorium kraju ${ }^{14}$.

Na zasady udzielania świadczeń zdrowotnych w ramach Narodowej Służby Zdrowia istotny wpływ ma także organizacja i funkcjonowanie NHS foundation trusts. Zostały one utworzone na podstawie przepisów ustawy Health and Social Care (Community Health and Standards) Act z 2003 r. ${ }^{15}$ Są to samozarządzające się podmioty ochrony zdrowia (szpitale). Funkcjonują one jako organizacje pożytku publicznego niedziałające w celu osiągnięcia zysku. Nie posiadają również udziałowców ani akcjonariuszy. NHS foundation trusts nie mogą pobierać jakichkolwiek opłat od pacjentów ani zmieniać na niekorzyść stawek obowiązujących dotychczas dla świadczeń zdrowotnych udzielanych poza strukturą Narodowej Służby Zdrowia $^{16}$. Głównym celem ich funkcjonowania jest dostarczanie towarów i usług na rzecz publicznego systemu ochrony zdrowia. NHS foundation trusts mają także prawo świadczyć usługi związane z udzielaniem świadczeń zdrowotnych w prywatnym sektorze ochrony zdrowia z zastrzeżeniem, że uzyskany z tego tytułu przychód w danym roku podatkowym nie może przekroczyć sumy przychodów osiągniętych z tytułu działalności prowadzonej na rzecz zdrowia publicznego. W innym przypadku

13 Tamże, s. 12-13 i 18.

14 J. Janas, Prywatyzacja brytyjskiego sektora publicznego na przykładzie National Health Service, Wrocław 2015, praca doktorska obroniona na Wydziale Prawa, Administracji i Ekonomii Uniwersytetu Wrocławskiego - maszynopis niepublikowany, s. 133.

15 Health and Social Care (Community Health and Standards) Act 2003, chapter 43.

16 J. Janas, Prywatyzacja brytyjskiego sektora publicznego..., s. 119 i n. 
NHS foundation trusts nie będą spełniać głównego (zasadniczego) celu swojej działalności (art. 164 HSC Act 2012).

\section{3. Źródła finansowania brytyjskiego systemu ochrony zdrowia}

Jak to już wskazano wyżej, brytyjski system ochrony zdrowia jest finansowany z dochodów budżetu państwa (Funduszu Skonsolidowanego) ${ }^{17}$. Do głównych dochodów angielskiego budżetu zalicza się przede wszystkim podatki dochodowe, podatek od wartości dodanej, a także wpływy z podatku akcyzowego obciążającego działalność z zakresu produkcji paliw, wyrobów alkoholowych oraz tytoniowych ${ }^{18}$. Ponad $75 \%$ środków przeznaczanych na finansowanie Narodowej Służby Zdrowia pochodzi z budżetu państwa. Oznacza to, że budżet ten jest głównym źródłem jej finansowania, ale nie jedynym. NHS finansowana jest w ok. 20\% ze środków pochodzących z systemu ubezpieczeń społecznych. Środki przeznaczane na ochronę zdrowia stanowią w Anglii drugą największą pozycję wśród wydatków publicznych ${ }^{19}$. Ogólna kwota wydatków publicznych dokonywanych na pokrycie kosztów systemu ochrony zdrowia stanowi bowiem 18\% całości budżetu w ujęciu rocznym powiększonych o składki pobierane $\mathrm{w}$ ramach systemu ubezpieczenia społecznego ${ }^{20}$.

Podmiotem odpowiedzialnym za gromadzenie, w ramach budżetu państwa, środków publicznych oraz zarządzanie finansami publicznymi jest Kanclerz Skarbu (Chancellor of the Exchequer) kierujący ministerstwem finansów. Do jego zadań należy przede wszystkim podejmowanie okresowych kontroli wydatków publicznych w celu ustalenia stałych i niezmienny limitów wydatków przypadających na poszczególne ministerstwa w okresie trzyletnim. W przypadku wydatków przeznaczanych

\footnotetext{
R. Harker, NHS Funding and expenditure, House of Commons Library 2011, s. 3.

S. Boyle, Health Systems in Transition. United Kingdom..., s. 85.

19 Pierwsze miejsce zajmuje realizacja wydatków na rzecz systemu ubezpieczenia społecznego.

20 P. Davies, The concise NHS handbook 2013/14. The essential guide to the new NHS in England, London 2013, s. 110.
} 
na finansowanie systemu ochrony zdrowia trzyletni okres ich planowania nie zawsze jest przestrzegany ${ }^{21}$.

$\mathrm{W}$ angielskim systemie budżetowym wydatki publiczne dzielą się na dwie kategorie. Do pierwszej z nich należą wydatki ujmowane w wieloletnim limicie wydatków resortowych (departamental expenditure limit) ${ }^{22}$. Wydatki te są planowane na trzyletnie okresy, w ramach kontroli, o której mowa wyżej. Drugą kategorię wydatków publicznych stanowią annualy manager expenditure. Są to wydatki, które nie mogą podlegać wieloletnim limitom według tych samych zasad, które stosuje się do wydatków ujmowanych w wieloletnim limicie wydatków resortowych. Suma wydatków zaliczanych do wskazanych dwóch kategorii stanowi całość wydatków publicznych w Anglii. W ostatnich latach wydatki ujmowane w wieloletnim limicie wydatków resortowych przeznaczane na finansowanie Narodowej Służby Zdrowia przekroczyły 110 mld funtów w ujęciu rocznym ${ }^{23}$.

Po dokonaniu przez Kanclerza Skarbu przydziału środków pochodzących z budżetu państwa Sekretarz Stanu do spraw Zdrowia podejmuje decyzję w przedmiocie podziału otrzymanych zasobów pomiędzy poszczególne jednostki NHS ${ }^{24}$. Przyznane środki są dzielone pomiędzy następujące rodzaje działalności Narodowej Służby Zdrowia: świadczenia podstawowej opieki zdrowotnej, świadczenia specjalistyczne oraz wydatki zespołów do spraw kontraktowania świadczeń medycznych odpowiedzialnych za zapewnienie świadczeń dodatkowych lub świadczeń środowiskowej opieki zdrowotnej ${ }^{25}$. Ponad $80 \%$ całości środków przeznaczanych na zadania realizowane przez podmioty funkcjonujące $\mathrm{w}$ ramach Narodowej Służby Zdrowia jest wydatkowana w celu zapewnienia pod-

21 W 2002 r. ustalono bowiem pięcioletni plan wydatków. W 2010 r. został natomiast uchwalony plan czteroletni obejmujący całość wydatków publicznych dokonywanych przez organy administracji rządowej. K. Wood (red.), Introductory guide to NHS Finance in the UK, Bristol 2011, s. 21-22.

Tamże, s. 22.

24 Przykładowo w okresie 2013-14 angielska Narodowa Służba Zdrowia otrzymała przydział środków w wysokości 95 mld funtów. Kwota 2,7 mld funtów została przekazana na zadania z zakresu ochrony zdrowia realizowane poza strukturą organizacyjną NHS.

25 P. Davies, The concise NHS handbook..., s. 113. 
stawowych świadczeń opieki zdrowotnych ${ }^{26}$. Kwota przyznanych środków na dany rok obrotowy nie ma charakteru stałego. Na podstawie art. 227 pkt 5 NHS Act 2006, Sekretarz Stanu jest upoważniony do zmiany wysokości przyznanych poszczególnym organom NHS środków pochodzących z budżetu centralnego.

Innym rodzajem kategoryzacji środków przeznaczanych na działalność NHS jest podział na wydatki o charakterze bieżącym i majątkowym. Do pierwszej grupy zalicza się wydatki dokonywane w celu finansowania wynagrodzeń personelu medycznego, pokrycia kosztów administracyjnych, zakupu usług oraz środków niezbędnych do funkcjonowania jednostek udzielających świadczeń zdrowotnych, a także na badania i rozwój. Tego rodzaju wydatki stanowią ok. 95\% całości środków przeznaczanych na funkcjonowanie Narodowej Służby Zdrowia ${ }^{27}$. Do drugiej kategorii wydatków zalicza się natomiast środki przeznaczane na nabycie nieruchomości oraz środków trwałych ${ }^{28}$.

W myśl art. 226 NHS Act 2006 organy zarządzające Narodową Służbą Zdrowia są zobowiązane do utrzymywania równowagi budżetowej w każdym roku obrotowym. Powołany przepis wyraża prawny nakaz dokonywania wydatków, których ogólna wysokość nie może przekroczyć łącznej kwoty dochodów uzyskiwanych przez poszczególne podmioty, w tym środków przyznanych pochodzących z budżetu państwa. Zgodnie z art. 226 pkt 3 NHS Act 2006 Sekretarz Stanu jest upoważniony do wydawania zaleceń organom Narodowej Służby Zdrowia, które w jego ocenie są niezbędne dla utrzymania stanu równowagi finansowej.

Dodatkowe wymogi w zakresie równoważenia dochodów i wydatków organów NHS zawiera art. 227 NHS Act 2006. Organy NHS są zobowiązane do zapewnienia, iż w danym roku obrotowym suma dokonywanych wydatków w ramach prowadzonej działalności nie przekroczy kwoty przyznanej im przez Sekretarza Stanu. W tym celu jest on upoważ-

${ }^{26}$ K. Wood (red.), Introductory guide to NHS Finance..., s. 26.

27 Ok. 60\% środków pozostających w dyspozycji NHS przeznaczanych jest na finansowanie wynagrodzeń osobowych.

28 T. White, J. Black, The Doctor's Handbook, Part 2. Understanding the NHS, Abingdon 2010, s. 128. 
niony do wydawania zaleceń określających sposoby wykorzystania otrzymanych środków. Ich moc wiążąca została uzależniona od indywidualnej decyzji Sekretarza Stanu (art. 227 pkt 2 i 3 NHS Act 2006).

Sposób wydatkowania środków publicznych pozostających w dyspozycji angielskiej NHS oparty jest o tzw. płatności za wyniki (payment by results). Był on stopniowo wprowadzany w celu zmiany sposobu przepływu zasobów finansowych pomiędzy podmiotami odpowiedzialnymi za kontraktowanie świadczeń zdrowotnych przysługujących w ramach Narodowej Służby Zdrowia a świadczeniodawcami. Zasadniczą cechą tego rodzaju zasad wydatkowania środków publicznych na ochronę zdrowia jest „podążanie zasobów finansowych za pacjentem”29.

Skutkiem funkcjonowania systemu payment by results ma być zwiększenie możliwości wyboru świadczeniodawców przez pacjenta korzystającego ze świadczeń NHS. Podmioty odpowiedzialne za zapewnienie określonego katalogu usług w ramach NHS nie zawierają umów ze świadczeniobiorcami, których przedmiotem jest nabycie określonej ilości świadczeń. Płatność oparta o system payment by results następuje dopiero po wykonaniu świadczenia. Wysokość wydatkowanych środków zależy zatem od liczby zrealizowanych świadczeń opieki zdrowotnej z zastrzeżeniem, że nie może przekroczyć limitów ustalonych przez angielskie ministerstwo zdrowia ${ }^{30}$. Ustala ono także taryfy kosztów (cenniki) poszczególnych usług z zakresu opieki zdrowotnej ${ }^{31}$. Wprowadzony system ma spowodować wzrost efektywności oraz jakości udzielanych w ramach NHS świadczeń oraz umożliwić obywatelom wybór świadczeniodawcy ${ }^{32}$.

W ostatnich latach następuje wyraźny wzrost wydatków publicznych dokonywanych w ramach Narodowej Służby Zdrowia. Jest to spowodowane zwiększeniem niezbędnych kosztów funkcjonowania systemu. Do czynników mających zasadniczy wpływ na zachodzące zmiany w zakresie

\footnotetext{
T. White, I. Carruthers, A Guide to the NHS, Abingdon 2010, s. 132-133.

30 A. Talbot-Smith, A.M. Pollock, C. Leys, N. McNally, The New NHS, London 2007, s. 96 i n.

31 K. Wood (red.), Introductory guide to NHS Finance..., s. 144-145.

32 Tamże, s. 144.
} 
potrzeb finansowych NHS zalicza się przede wszystkim: zwiększone zapotrzebowanie ze strony świadczeniobiorców na usługi przysługujące w ramach publicznego systemu zdrowotnego, konieczność wprowadzania innowacyjnych rozwiązań w zakresie wdrażanych procedur medycznych, styl życia mieszkańców, a także pojawiające się potrzeby dotyczące zdrowia psychicznego oraz opieki społecznej ${ }^{33}$.

Utrzymujący się wzrost kosztów funkcjonowania systemu ochrony zdrowia nie oznacza, iż działalność Narodowej Służby Zdrowia w ostatnich latach ma charakter deficytowy. NHS osiągała dotychczas regularne nadwyżki budżetowe będące efektem wprowadzenia skutecznej kontroli nad wydatkowaniem przyznanych środków oraz zmniejszeniem wydatków dokonywanych przez NHS trusts odpowiedzialnych za realizację świadczeń z zakresu podstawowej opieki zdrowotnej.

Jedynie 8\% podmiotów funkcjonujących w strukturze organizacyjnej Narodowej Służby Zdrowia nie zdołało osiągnąć równowagi finansowej, czego skutkiem było powstanie w ich planach finansowych deficytu. Nie przekracza on jednak $500 \mathrm{mln}$ funtów, co stanowi niewielką kwotę w porównaniu do całości środków wydatków publicznych przeznaczanych na realizację zadań z zakresu ochrony zdrowia przez $\mathrm{NHS}^{34}$. Liczba podmiotów pozostających w strukturze NHS generujących deficyt finansowy ma charakter zmienny. W niektórych okresach sprawozdawczych nie przekraczała nawet 3\% liczby wszystkich jednostek organizacyjnych Narodowej Służby Zdrowia ${ }^{35}$. Niski deficyt finansowy w sektorze ochrony zdrowia nie oznacza jednak, że NHS funkcjonuje w sposób prawidłowy. Jest ona poddawana ciągłym reformom mającym na celu wzrost efektywności oraz zwiększenie wydatków publicznych pochodzących z budżetu państwa na realizację zadań z zakresu ochrony zdrowia ${ }^{36}$.

Jak to już wyżej ustalono, drugim źródłem finansowania Narodowej Służby Zdrowia w Anglii jest składka pobierana w ramach systemu ubez-

\footnotetext{
P. Davies, The concise NHS handbook..., s. 117-118.

Tamże, s. 118.

T. White, J. Black, The Doctor's Handbook..., s. 125.

A. Street, The financial crisis in the National Health Insurance: insufficient funding will derail transformation plans, Radical Statistics 2016, s. 52-53.
} 
pieczenia społecznego (National Insurance Contributions). Ma ona jednak dużo mniejsze znaczenie dla funkcjonowania NHS. Tylko niewielka część dochodów uzyskiwanych z tytułu poboru składek na ubezpieczenie społeczne przeznaczana jest na realizację zadań państwa z zakresu ochrony zdrowia. Większość wpływów z ich tytułu zasila Narodowy Fundusz Ubezpieczeń (National Health Insurance). Zgodnie z sekcją 161 pkt 2 Social Security Administration Act z 1992 r. $^{37}$ jest on podmiotem pozostającym pod zarządem Służb Podatkowych i Celnych (Commissioners for Her Majesty's Revenue and Customs). Środki Narodowego Funduszu Ubezpieczeń są wydatkowane m.in. na finansowanie niektórych emerytur, zasiłki chorobowe, zasiłki opiekuńcze oraz zasiłki macierzyńskie i inne świadczenia związane z opieką nad dziećmi.

Składki pobierane przez brytyjskie urzędy skarbowe (Inland Revenue) przekazywane są na rachunek Narodowego Funduszu Ubezpieczeń po dokonaniu odliczenia przydziału środków z nich pochodzących na rzecz Narodowej Służby Zdrowia (sekcja 12 pkt 2 SSAC 1992). Wysokość części składki na ubezpieczenie społeczne przeznaczanej na finansowanie NHS nie jest ustalana w sposób jednolity i jest uzależniona od określonej kategorii (klasy) składki. Ok. 10\% wpływów z tytułu całości pobieranych składek ubezpieczeniowych jest przeznaczana na realizację zadań z zakresu ochrony zdrowia. Podkreślić także należy, że uiszczenie składki nie stanowi warunku uzyskania świadczeń zdrowotnych w ramach NHS ${ }^{38}$.

Konstrukcja prawna angielskich składek na ubezpieczenie społeczne została oparta o przynależność ubezpieczonego do określonej kategorii podmiotów. Zakwalifikowanie ubezpieczonych do danej klasy składki determinuje sposób ustalania jej wielkości oraz wysokość jej części, która jest przeznaczana na finansowanie zadań państwa z zakresu ochrony zdrowia. Sposób ustalania wysokości składki oraz zasady jej uiszczania wynikają z części I Social Security Contributions and Benefits Act z 1992 r. $^{39}$

37 Social Security Administration Act 1992, chapter 5, dalej: „SSAC 1992”.

38 J. Cylus, E. Richardson, L. Findley, M. Longley, C. O'Neill, D. Steel, Health Systems in Transition, „United Kingdom. Health system review”, 2015, nr 5, s. 51.

39 Social Security Contributions and Benefits Act 1992, chapter 4; dalej: "SSCBA”. 
Zgodnie z sekcją 1 SSCBA podmioty zobowiązane do uiszczania składek ubezpieczeniowych zostały zakwalifikowane do 7 kategorii (klas). Do poszczególnych klas zaliczono przede wszystkim pracowników i inne osoby wykonujące na terenie Wielkiej Brytanii pracę zarobkową, osoby prowadzące działalność gospodarczą, w tym osoby zarabiające na własny rachunek w innej formie niż umowa pracę, inne osoby uzyskujące przychody, a także osoby dobrowolnie ubezpieczone w celu nabycia uprawnień emerytalnych.

Podstawą wymiaru składek na ubezpieczenie społeczne dla większości podmiotów zobowiązanych do ich zapłaty jest uzyskany przez nich przychód, np. z tytułu świadczenia pracy (bez względu na rodzaj zatrudnienia) bądź z tytułu prowadzenia działalności gospodarczej. Stawki w brytyjskiej składce ubezpieczeniowej mają charakter procentowy i wynoszą zasadniczo od $12 \%$ do $14,25 \%$ podstawy wymiaru. Wysokość stawki składki uzależniona jest od uzyskiwanych przychodów oraz przynależności do określonej kategorii ubezpieczonych.

Organy Narodowej Służby Zdrowia nie mają żadnego wpływu na zasady ustalania wysokości składek $\mathrm{w}$ angielskim ubezpieczeniu społecznym. Nie mają także uprawnień w zakresie poboru składki. NHS otrzymuje jedynie ustaloną w sposób procentowy część składki. Wysokość udziału w składce na ubezpieczenie społeczne ma charakter zróżnicowany. Zasady jego ustalania wynikają z sekcji 162 pkt 5 lit. a-f SSCBA. W przypadku osób ubezpieczonych zaliczanych do kategorii 1, 1A i 1B wysokość przekazywanej na rzecz NHS składki wynosi zasadniczo ponad 2\% ogólnej jej kwoty powiększonej o 7,5\% kwoty składki dodatkowej. Udział Narodowej Służby Zdrowia w składkach osób ubezpieczonych zaliczanych do kategorii 2 i 3 wynosi $15,5 \%{ }^{40}$. W angielskim ubezpieczeniu społecznym istnieje także składka dodatkowa. Część tego rodzaju składki również jest przekazywana na rzecz systemu ochrony zdrowia. Narodowej Służbie Zdrowia przysługuje 7,5\% całości składki dodatkowej bez względu na kategorię, do której zaliczani są ubezpieczeni. Istnieje jednak możliwość modyfikacji przez organy administracji rządowej w formie rozpo-

40 Część składek ubezpieczeniowych w kategorii 4 przekazywanych na rzecz NHS wynosi natomiast 2,15\% ich całości. 
rządzeń wysokości składek przekazywanych na rzecz NHS (sekcja 162 pkt 7 SSBCA).

Udział Narodowej Służby Zdrowia we wpływach z tytułu składki na ubezpieczenie społeczne nie może jednak oznaczać, że angielski system zdrowotny jest chociażby w części modelem ochrony zdrowia opartym o ubezpieczeniową metodę finansowania. Podleganie ubezpieczeniu społecznemu nie determinuje bowiem zakresu świadczeń przysługujących w ramach NHS. Są to dwa odrębne i niezależne od siebie systemy. Świadczeniobiorca $\mathrm{w}$ angielskim modelu ochrony zdrowia nie musi być osobą ubezpieczoną w Narodowym Funduszu Ubezpieczeń.

Źródłem finansowania Narodowej Służby Zdrowia w Anglii są także opłaty pobierane w związku z udzielaniem określonych świadczeń zdrowotnych oraz usług medycznych ${ }^{41}$. Dochody uzyskiwane z tego tytułu mają charakter marginalny w porównaniu do całości środków pochodzących z budżetu centralnego oraz ze składek na ubezpieczenia społeczne przeznaczanych na realizację zadań z zakresu ochrony zdrowia. Obecnie dochody z tytułu opłat stanowią ok. 2\% całości środków pozostających w dyspozycji NHS ${ }^{42}$.

Opłaty w angielskim systemie ochrony zdrowia pobierane są przede wszystkim z następujących tytułów: wystawienie recepty, zabiegi dentystyczne oraz badanie wzroku ${ }^{43}$. Obowiązuje jednak zasada, że opłaty związane z udzielaniem świadczeń w ramach NHS powinny być pobierane jedynie od osób, których sytuacja majątkowa pozwala na ich uiszczenie. W związku z tym istnieje szeroki katalog zwolnień z obowiązku ponoszenia części kosztów świadczeń zdrowotnych w postaci uiszczenia opłat (zwolnienia mają głównie charakter podmiotowy i dotyczą m.in. osób osiągających niskie dochody, osób bezrobotnych, a także osób starszych). Przyjmuje się, że na skutek wprowadzonych zwolnień ok. połowa osób uprawnionych do świadczeń w ramach Narodowej Służby Zdrowia

\footnotetext{
41 A. Oliver, The English National Health Service: 1979-2005, "Health Economics" 2005, nr 14, s. 83-86.

P. Davies, The concise NHS handbook..., s. 111.

43 Narodowa Służba Zdrowia w Walii, Szkocji oraz Irlandii Północnej nie pobiera opłat $\mathrm{z}$ tytułu wystawiania świadczeniobiorcom recept.
} 
nie jest zobowiązana do uiszczania opłat z tytułu otrzymywanych recept. W angielskim systemie ochrony zdrowia wyklucza się jednocześnie całkowitą rezygnację z tego rodzaju opłat. Wskazuje się bowiem, że ich likwidacja zmniejszyłaby budżet NHS o ok. 450 mln funtów ${ }^{44}$.

Dodatkowe źródło finansowania stanowią także koszty udzielonych w ramach NHS świadczeń zdrowotnych ofiarom wypadków komunikacyjnych. Tego rodzaju koszty są pobierane w formie opłat od instytucji ubezpieczeniowych, w których ubezpieczeni są sprawcy wypadków. Opłaty pobierane w związku z udzielaniem świadczeń ofiarom wypadków komunikacyjnych są pobierane m.in. z tytułu wykorzystania karetki pogotowia, leczenia szpitalnego, a także leczenia ambulatoryjnego bez konieczności hospitalizacji ${ }^{45}$.

Do katalogu źródeł finansowania Narodowej Służby Zdrowia nie zalicza się natomiast budżetów samorządowych, których zasadnicza część dochodów pochodzi z tytułu podatków lokalnych. Z budżetów samorządowych są finansowane jedynie wydatki dokonywane w celu realizacji zadań z zakresu zabezpieczenia społecznego. Zalicza się do nich m.in. opiekę domową, a także funkcjonowanie domów opieki społecznej ${ }^{46}$.

\section{Wnioski}

W brytyjskiej literaturze z zakresu ochrony zdrowia podkreśla się, że system zdrowotny oparty o model budżetowy jest wysoce efektywnym sposobem finansowania opieki zdrowotnej ${ }^{47}$. Przyjmuje się, że wykorzystywanie zasobów finansowanych pochodzących z podatków ogólnych i stanowiących dochody budżetu państwa powoduje w systemie Narodowej Służby Zdrowia zwiększenie kontroli organów administracji rządowej nad dokonywanymi wydatkami. Ponadto, tego rodzaju sposób finansowania ochrony zdrowia nie generuje wysokich kosztów administracyjnych przeznaczanych na obsługę systemu zdrowotnego. Dochody budżetu cen-

\footnotetext{
P. Davies, The concise NHS handbook..., s. 111.

Tamże, s. 111.

S. Boyle, Health Systems in Transition. United Kingdom..., s. 88.

P. Davies, The concise NHS handbook..., s. 110.
} 
tralnego pochodzą z wielu źródeł. Model ochrony zdrowia oparty o Narodową Służbę Zdrowia pozwala zatem uniknąć negatywnych skutków wystąpienia deficytu w poszczególnych sektorach gospodarki ${ }^{48}$.

Do zalet modelu Narodowej Służby Zdrowia zalicza się głównie powszechny dostęp do świadczeń opieki zdrowotnej udzielanych w ramach publicznego systemu przez wszystkich obywateli, a także zapewnienie ich nieodpłatności. Wskazuje się, że walorem analizowanego modelu jest gwarancja otrzymania środków finansowych z budżetu państwowego. Za pozytywne cechy uznaje się również centralną kontrolę nad systemem oraz nałożenie na organy administracji państwowej odpowiedzialności za udzielanie świadczeń opieki zdrowotnej, a także za stan zdrowia społeczeństwa $^{49}$. W przeciwieństwie do modelu ubezpieczeniowego ochrony zdrowia w modelu Beveridge’a państwo ponosi całkowitą odpowiedzialność za zapewnienie świadczeń opieki zdrowotnej swoim obywatelom.

Jako wady modelu Beveridge’a wskazuje się przede wszystkim ograniczoną możliwość wyboru przez pacjenta świadczeniodawcy oraz upolitycznienie decyzji dotyczących organizowania i finansowania udzielanych świadczeń ${ }^{50}$. Oceniając skuteczność i efektywność brytyjskiego modelu ochrony zdrowia opartego o budżetową metodę finansowania, wskazuje się również inne jego wady. Wydatkowanie środków publicznych pochodzących z budżetu państwa na zadania z zakresu ochrony zdrowia determinowane jest subiektywnymi działaniami organów administracji rządowej. Od decyzji organów, do których kompetencji należy ustalenie poziomu finansowania poszczególnych rodzajów zadań publicznych, zależy bowiem wysokość środków przekazanych do dyspozycji Narodowej Służby Zdrowia. Zakres usług świadczonych w ramach publicznego systemu ochrony zdrowia, a także wysokość oraz sposób ich finansowania są ustalane centralnie ${ }^{51}$.

48 Tamże. s. 110.

49 A. Rabiega, Ochrona życia i zdrowia ludzkiego w działaniach podmiotów administrujacych w sferze opieki zdrowotnej, Warszawa 2009, s. 48.

50 A. Przybyłka, Przyczyny i uwarunkowania systemowych rozwiq̨zań opieki zdrowotnej, „Antidotum - Zarządzanie w Opiece Zdrowotnej” 2003, nr 2, s. 63.

51 P. Davies, The concise NHS handbook..., s. 110-111. 
W przypadku budżetowego modelu finansowania ochrony zdrowia, którego klasycznym przykładem jest angielska Narodowa Służba Zdrowia, dochodzi do sytuacji, w której wydatki publiczne przeznaczane na świadczenia zdrowotne dla obywateli muszą konkurować z innymi wydatkami budżetowymi. Nie istnieją bowiem mechanizmy prawne pozwalające na zagwarantowanie określonej wysokości środków publicznych, która zapewnia prawidłową realizację zadań państwa związanych z organizacją systemu opieki zdrowotnej na poziomie dostosowanym do indywidualnych i zbiorowych potrzeb obywateli oraz odpowiadającym właściwym standardom wynikającym z rozwoju nauk medycznych.

Analiza systemu Narodowej Służby Zdrowia w Wielkiej Brytanii prowadzi także do wniosku, iż budżet państwa nie jest w pełni wystarczającym źródłem finansowania ochrony zdrowia z punktu widzenia potrzeb obywateli jako świadczeniobiorców. Mimo że jest on zasadniczym źródłem finansowania, NHS musi posiadać także m.in. udział we wpływach z tytułu poboru składki na ubezpieczenie społeczne, które w Wielkiej Brytanii jest oddzielone instytucjonalnie i organizacyjnie od systemu ochrony zdrowia. Brytyjska Narodowa Służba Zdrowia jest przykładem tego, iż środki finansowe pochodzące z jednego zasobu środków publicznych nie są wystarczające dla pokrycia całości wydatków przeznaczanych na realizację zadań państwa z zakresu ochrony zdrowia. Niezbędna jest zatem dywersyfikacja źródeł finansowania.

\section{Bibliografia:}

Boyle S., Health Systems in Transition. United Kingdom (England), „Health System Review” 2011, European Observatory one Health Systems and Policies.

Cylus J., Richardson E., Findley L., Longley M., O’Neill C., Steel D., Health Systems in Transition. „United Kingdom. Health system review”, 2015, nr 5, European Observatory one Health Systems and Policies.

Davies P., The concise NHS handbook 2013/14. The essential guide to the new NHS in England, London 2013, The NHS Confederation.

Depta A. Transformacja współczesnych systemów zdrowotnych w wybranych krajach, [w:] Suchecka J. (red.), Finansowanie ochrony zdrowia. Wybrane zagadnienia, Wolters Kluwer, Warszawa 2011. 
Harker R., NHS Funding and expenditure, House of Commons Library 2011.

Janas J., Prywatyzacja brytyjskiego sektora publicznego na przykładzie National Health Service, Wrocław 2015, praca doktorska obroniona na Wydziale Prawa, Administracji i Ekonomii Uniwersytetu Wrocławskiego - maszynopis niepublikowany.

Merrils J., Fisher J., Pharmacy Law and Practice, Oxford 2013.

Oliver A., The English National Health Service: 1979-2005, "Health Economics" 2005, nr 14, ss. 75-99.

Przybyłka A., Przyczyny i uwarunkowania systemowych rozwiq̨zań opieki zdrowotnej, „Antidotum - Zarządzanie w Opiece Zdrowotnej” 2003, nr 2, ss. 55-60.

Rabiega A., Ochrona życia i zdrowia ludzkiego w działaniach podmiotów administrujących w sferze opieki zdrowotnej, Wydawnictwo Sejmowe, Warszawa 2009.

Street A., The financial crisis in the National Health Insurance: insufficient funding will derail transformation plans, Radical Statistics 2016, ss. 37-53.

Talbot-Smith T., Pollock A.M., Leys C., McNally N., The New NHS, Routledge, London 2007.

Urbaniak M., Aspekty publicznoprawne organizacji i finansowania ochrony zdrowia w Republice Włoskiej, TNOiK, Toruń 2014.

White T., Black J., The Doctor's Handbook, Part 2. Understanding the NHS, CRC Press, Abingdon 2010.

White T., Carruthers I., A Guide to the NHS, CRC Press, Abingdon 2010.

Włodarczyk W., Polityka zdrowotna w społeczeństwie demokratycznym, Uniwersyteckie Wydawnictwo Medyczne Vesalius, Łódź-Kraków-Warszawa 1996.

Wood K. (red.), Introductory guide to NHS Finance in the UK, Healthcare Financial Management Association, Bristol 2011. 